\title{
OPTIMALISASI AKAD MUZARA'AH PADA BANK SYARIAH
}

\author{
Irwan Rahmatullah Putra \\ Perumahan Bluru Permai BB-06 RT 02 RW 10 Sidoarjo
}

\author{
M. Syahrul Hajj \\ Simo Mulyo Baru 3B No. 19
}

\author{
Ikayanti \\ Jl. Jemur Wonosari Gang Lebar No. 128 Surabaya \\ flashroom@ymail.com
}

\begin{abstract}
This article discusses the optimization of muzara'ah contracts in Islamic banks. This article is the result of a literature review and qualitative research. Data comes from literature in the form of books, journal articles, and the internet, which after being collected are analyzed descriptively. The results of the study are muzara'ah is cultivating other people's land such as rice fields or fields in exchange for a portion of the yield (one-half, one-third, or one-quarter), while the labor costs and seeds are borne by the landowner. Ulama have different opinions about the law of muzara'ah, some are permissible and some are forbidden. For those who allow, muzara'ah must meet the pillars and conditions that have been determined. Rukun muzara'ah is landowners, farmers/cultivators, objects of muzara'ah, and Ijab and qabul. The practice of muzara'ah refers to the principles of the Profit and Loss Sharing System. In optimizing the muzara'ah contract on Islamic banks, it is necessary to improve the bank system according to the real vision of the Islamic bank and improve the agricultural system. Muzara'ah financing is very important for farmers who want to develop their agricultural land so that they can create mutual benefit, which means good quality and income from individuals and socially. Therefore, Islamic banks play an important role in implementing the muzara'ah contract in Indonesia, of course with the support of the community and government, including through controlling demand and supply, fixing prices, spurring the emergence of an investment climate, not stopping improving the quality of human resources, and maximizing technology.
\end{abstract}

Keywords: syariah bank, muzara'ah, maslahat, syariah.

Abstrak: Artikel ini membahas tentang optimalisasi akad muzara'ah pada bank syariah. Artikel ini merupakan hasil kajian pustaka dan kualitatif. Data berasal dari literer berupa buku, artikel jurnal dan internet, yang setelah terkumpu dianalisis secara deskriptif. Hasil penelitian adalah muzara'ah adalah menggarap tanah orang lain seperti sawah atau ladang dengan imbalan sebagian hasilnya (seperdua, sepertiga atau seperempat), sedangkan biaya pengerjaan dan benihnya ditanggung pemilik tanah. Ulama berbeda pendapat tentang hukum muzara'ah, ada yang membolehkan dan ada yang mengharamkan. Bagi yang membolehkan, muzara'ah

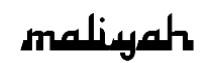

Jurnal Hukum Bisnis Islam

Volume 8, Nomor 2, Desember 2018

p-ISSN: 2088-4869/ e-ISSN: 2597-4351 
harus memenuhi rukun dan syarat yang telah ditentukan. Rukun muzara'ah adalah Pemilik tanah, petani/penggarap, objek muzara'ah, dan Ijab dan qabul. Praktek muzara'ah mengacu pada prinsip Profit and Loss Sharing System. Dalam optimalisasi akad muzara'ah pada bank syariah, maka perlu memperbaiki sistem bank sesuai visi bank syariah yang sesungguhnya dan memperbaiki sistem pertanian. Pembiayaan muzara'ah sangat penting bagi petani yang ingin mengembangkan lahan pertaniannya agar dapat terwujudnya kemaslahatan bersama yang artinya bagus dalam kualitas dan pendapatannya dari individu maupun sosial. Karena itu bank syariah sangat berperan penting dalam penerapan akad muzara'ah di Indonesia, tentunya dengan dukungan dari masyarakat dan pemerintah, diantaranya melalui pengendalian permintaan dan penawaran, penetapan harga, memacu timbulnya iklim investasi, tidak berhenti meningkatkan mutu SDM, dan memaksimalkan teknologi.

Kata Kunci: bank syariah, muzara'ah, maslahat, syariah.

\section{Pendahuluan}

Dewasa ini standar pengukuran taraf kehidupan individu maupun suatu negara adalah sektor perekonomiannya. Ukuran derajat seseorang dinilai dari sisi perekonomiannya. Pada dasarnya bekerja adalah suatu kewajiban bagi setiap manusia, banyak sektor-sektor pekerjaan yang bisa kita lakukan, terlebih lagi Indonesia adalah negara agraris. Pekerjaan yang bisa dilakukan salah satunya adalah pada sektor pertanian.

Pada masyarakat pedesaan sebagian besar hanya menggantungkan hidupnya dari hasil pertanian, dimana taraf kesejahteraan (kemaslahatan) mereka berbeda-beda. Sebagian dari mereka ada yang memiliki lahan sendiri untuk digarap dan sebagian tidak memiliki lahan sendiri untuk digarap. Bagi yang tidak punya lahan, maka untuk mencukupi kebutuhannya, mereka bekerjasama dengan yang memiliki lahan untuk menggarap lahan pertaniannya dengan imbalan bagi hasil.

Dari keadaan masyarakat diatas dapat ditarik munculnya akad pembiayaan muzara'ah oleh bank syariah selaku pihak parties to mediate. Akan tetapi pada kenyataannya, bank pada umumnya tidak melakukan pembiayaan pada sektor ini.

Dalam menyalurkan kredit pada sektor pertaniah pada umumnya perbankan syariah tidak menerapkan akad 
muzara'ah mengingat resiko yang harus ditanggung oleh perbankan relatif tinggi. ${ }^{1} \mathrm{Hal}$ ini menunjukkan keberpihakan perbankan syariah untuk melakukan tujuan ekonomi Islam itu sendiri menjadi diragukan. Padahal prinsip awal perbankan syariah adalah saling menolong dan membantu pemberdayaan rakyat demi tercapainya kemaslahatan. Berdasarkan hal tersebut, penulis tertarik membahas tentang optimalisasi akad muzara'ah pada bank syariah.

Penelitian ini merupakan hasil kajian pustaka dan bersifat kualitatif. Data didapat melalui kepustakaan yang berasal dari buku, artikel dan internet. Setelah terkumpul data dianalisis secara deskriptif.

\section{Pengertian Muzara'ah}

Menurut bahasa, muzara'ah adalah muamalah terhadap tanah dengan imbalan sebagian dari hasil tanah yang digarap. ${ }^{2}$ Sulaiman Rasyid dalam kitabnya Fiqh Islam mendefinisikan muzara'ah bahwa ia adalah menggarap tanah orang lain seperti sawah atau ladang dengan imbalan sebagian hasilnya (seperdua, sepertiga atau seperempat), sedangkan biaya pengerjaan dan benihnya ditanggung pemilik tanah. Hampir mirip dengan muzara'ah adalah mukhabarah yaitu seseorang menggarap tanah (orang lain) seperti sawah atau ladang dengan imbalan sebagian hasilnya (seperdua, sepertiga, atau seperempat), dan biaya pengerjaan dan benihnya ditanggung orang yang mengerjakannya. ${ }^{3}$

Berdasarkan definisi di atas, maka dapat diketahui bahwa muzara'ah adalah muamalah atas tanah dengan pembagian

1 Muhammad Ngasifudin, "Aplikasi Muzara'ah Dalam Perbankan Syariah," Jurnal Ekonomi Syariah Indonesia 6, no. 1 (2016), 38.

2 Abdul Azhim bin Badawai Al-Khalafi, Al-Wajiz Fi Fiqh as Sunnah Wa Al Kitab Al Aziz, Edisi Indonesia Panduan Fiqih Lengkap, Ter. Team Tashfiyah LIPIA (Jakarta: Pustaka Ibnu Kasir, 2007).

${ }^{3}$ Sulaiman Rasjid, Fiqih Islam (Bandung: Sinar Baru Algensindo, 2004). 
dari hasil penggarapan tanah tersebut. Muzara'ah berarti kerjasama antara pemilik lahan dengan petani penggarap dimana pemilik lahan memberikan tanah kepada petani untuk digarap agar dia mendapatkan bagian dari hasil tanamannya.

Berikut ini adalah pendapat-pendapat dari beberapa ulama tentang muzara'ah:

1. Menurut Ulama Hanafi

Muzara'ah adalah suatu akad perjanjian penglolaan tanah dengan memperoleh hasil sebagian dari penghasilan tanah itu. Dalam hal ini penggarap (petani) diperkenankan bertindak sebagai penyewa, untuk menanami tanah dengan imbalan biaya dari sebagian hasil tanamannya. Dalam hal ini, pemilik lahan juga diperbolehkan hanya mempekerjakan petani dengan upah dari hasil sebagian tanaman yang tumbuh pada tanah itu.

Imam Abu Hanifah dan Zufar bin Huzail tidak membolehkan akad muzara'ah dengan bagi hasil, seperti seperempat dan seperdua hukumnya batal, ${ }^{4}$ berdasarkan hadis riwayat Rafi' bin Khudaij, yang artinya: "Rasulullah melarang melakukan al-muzara'ah". (HR. Muslim).

Obyek akad dalam muzara'ah dinilai memiliki dimensi spekulatif karena kadarnya tidak jelas, bahwa yang dijadikan imbalan untuk petani adalah hasil panen yang belum ada (ma'dum) dan tidak jelas (jahalah) ukurannya, sehingga keuntungan yang akan dibagikan tidak jelas. Ketika panen bisa saja terjadi kegagalan dan si petani tidak mendapat apaapa dari garapannya, sehingga akad ini berpotensi terjadi adanya kerugian, kedzaliman yang hal tersebut bertentangan dengan prinsip ekonomi Islam.

Berkaitan dengan dalil yang melegitimasi keabsahan akad muzara'ah tentang perbuatan Rasulullah SAW terhadap penduduk Khaibar, bukanlah termasuk akad muzara'ah, melainkan al-kharaj al-muqasamah yaitu ketentuan pajak

\footnotetext{
${ }^{4}$ Nasroen Haroen, Fiqh Muamalah (Jakarta: Gaya Media Pratama, 2000), 276.
} 
yang harus dibayarkan kepada Rasulullah SAW setiap kali panen dalam prosentase tertentu.

2. Menurut Ulama Maliki

Muzara'ah adalah perjanjian kerjasama antara pemilik lahan dengan petani sebagai penggarap. Dalam hal ini pemilik lahan menyerahkan tanahnya kepada petani untuk ditanami, dan upah dari pengelolaan tersebut diambil dari hasil tanaman yang ditanam pada lahan tersebut. Jika pemilik lahan ikut membiayai penggarapan itu, seperti menyediakan bibit, maka si petani penggarap diperbolehkan mendapat upah berupa sejumlah uang atau berupa sebagian dari tanah dan tanaman yang dikelolanya sesuai dengan kesepakatan mereka berdua.

3. Menurut ulama syafi'i

Muzara'ah adalah kerjasama antara pemilik tanah dengan petani untuk menggarap atau mengelola lahan itu, dengan upah atau imbalan sebagian dari hasil pengelolaannya. Dalam hal ini bibit atau benih tanaman berasal dari pemilik lahan, petani hanya membuka lahan, menanami, dan memeliharanya hingga memperoleh hasil. Jika bibit atau benihnya berasal dari petani, maka disebut mukharabah. Hukum keduanya adalah tidak sah, karena menyewakan tanah dengan imbalan dari hasil pengelolaan, yang bisa saja petani mengalami kerugian apabila gagal panen karena halhal yang tidak diinginkan.

Dari pengertian muzara'ah menurut ulama di atas, maka dapat dipahami bahwa yang disebut muzara'ah adalah perjanjian kerjasama antara pemilik lahan pertanian dengan petani penggarap, yang upahnya diambil dari hasil pertanian yang sedang diusahakan. Sebagian ulama tidak membolehkan muzara'ah, karena petani penggarap dianggap belum jelas akan mendapatkan hasil dari pekerjaannya itu. ${ }^{5}$

\footnotetext{
5 Akafa, "Pengertian Muzara'ah," 2012, http://akafapendidikan.blogspot.com/2012/01/pengertianmuzaraah.html?zx=a9a2170cc9273cfb.
}

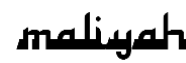

Jurnal Hukum Bisnis Islam

Volume 8, Nomor 2, Desember 2018 p-ISSN: 2088-4869/ e-ISSN: 2597-4351 


\section{Mekanisme Muzara'ah}

Menurut jumhur ulama (yang membolehkan akad muzara'ah) apabila akad telah memenuhi rukun dan syarat, maka akibat hukumnya adalah:

1. Petani bertanggung jawab mengeluarkan biaya benih dan pemeliharaan pertanian tersebut.

2. Biaya pertanian seperti pupuk, biaya perairan, serta biaya pembersihan tanaman, ditanggung oleh petani dan pemilik lahan sesuai dengan persentase bagian masing-masing.

3. Hasil panen dibagi sesuai dengan kesepakatan bersama.

4. Pengairan dilaksanakan sesuai dengan kesepakatan bersama dan apabila tidak ada kesepakatan, berlaku kebiasaan di tempat masing-masing.

5. Apabila salah seorang meninggal dunia sebelum panen, maka akad tetap berlaku sampai panen dan yang meninggal diwakili oleh ahli warisnya. Lebih lanjut, akad itu dapat dipertimbangkan oleh ahli waris, apakah akan diteruskan atau tidak. ${ }^{6}$

Secara teknis, kontrak muzara'ah tidak berbeda jauh dengan kontrak mudharabah. Hanya saja muzara'ah berarti khusus untuk pengolahan lahan pertanian sebagai pengganti dari produksi yang diatur oleh suatu aturan tertentu. Oleh karena itu, teknis pengaplikasian sistem ini dalam perbankan syariah hampir sama dengan sistem pembiayaan mudharabah. ${ }^{7}$

Pada prakteknya akad ini mengacu pada prinsip profit and loss sharing system, yaitu yang menjadi ukuran nisbah bagi

${ }^{6}$ Radian Ulfa, “Analisis Pengaruh Muzara'ah Terhadap Tingkat Kesejahteraan Petani (Studi Kasus Di Desa Simpang Agung Kabupaten Lampung Tengah)" (IAIN Metro, 2017), 15.

7 Afrik Yunari, "Muzara'ah Dan Aplikasinya Pada Perbankan Syari'ah," Inovatif 2, no. 2 (2016), 180. 
hasilnya adalah hasil akhir akad. ${ }^{8}$ Apabila hasil yang diperoleh berupa keuntungan, maka hasil tersebut akan dibagikan kepada kedua belah pihak. Begitu pula sebaliknya, jika hasilnya adalah rugi maka kedua pihak waib menanggung kerugiannya bersama. Praktek tersebut sangat mudah dan adil apabila perbankan mau mengaplikasikannya pada akan yang ada di sistem perbankan. Karena pada umumnya masyarakat Indonesia khususnya masyarakat tanah Jawa telah mengenal bahkan mempraktekkan akad ini dengan istilah maro, mertelu, dan merapat ${ }^{9}$. Di Jawa Barat dikenal dengan istilah negah atau jejuron, di Lombok juga disebut dengan nyangkap, dan di Minahasa disebut dengan toyo. ${ }^{10}$ Istilah-istilah daerah tersebut memiliki kesamaan dengan akad muzara'ah.

Pembagian hasil dalam Islam pun tidak jauh dari kebiasaan masyarakat Jawa seperti setengah, sepertiga, seperempat atau lebih dari itu ataupun bisa saja kurang dari itu. Tentunya dengan kesepakatan antara pemilik tanah dan pengolah tanah. Dari kesepakatan pembagian hasil tersebut diharapkan seluruh elemen masyarakat baik kalangan atas maupun bawah mencapai kemaslahatan.

\section{Dasar-dasar yang Melandasi Hukum Muzara'ah}

Landasan hukum disyariatkannya muzara'ah antara lain hadis riwayat dari Ibnu Umar bahwa Rasulullah SAW pernah memberikan tanah di Khaibar kepada penduduknya (waktu itu mereka masih Yahudi) untuk digarap dengan imbalan pembagian hasil buah-buahan dan tanaman. Begitu juga Ijma

\footnotetext{
${ }^{8}$ Suherman, "Penterapan Prinsip Bagi Hasil Pada Perbankan Syariah Sebuah Pendekatan Al-Maqasidu Al-Syariah," Al Mashlahah Jurnal Hukum Dan Pranata Sosial Islam 2, no. 3 (2014), 296.

${ }^{9}$ Martua Sihaloho, Heru Purwandari, and Dyah Ita Mardiyaningsih, "Reforma Agraria Dan Revitalisasi Pertanian Di Indonesia:Studi Kasus Pertanian Tanaman Pangan Dan Hortikultura Di Jawa Barat," Sodality: Jurnal Transdisiplin Sosiologi, Komunikasi, Dan Ekologi Manusia 4, no. 1 (2010), 151. ${ }^{10}$ Zainuddin S and Eno Suhandani, "Muzara'ah Dan Kesejahteraan Masyarakat Luwu Timur,” Jurnal Muamalah 6, no. 1 (2016), 26.
}

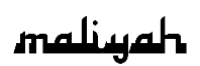

Jurnal Hukum Bisnis Islam

Volume 8, Nomor 2, Desember 2018 p-ISSN: 2088-4869/ e-ISSN: 2597-4351 
sebagaimana dikatakan Abu Ja'far: “Tidak ada satu rumah pun di Madinah kecuali penghuninya mengolah tanah secara muzara'ah dengan pembagian hasil 1/3 dan 1/4". Hal ini telah dilakukan oleh Sayyidina Ali, Sa'ad bin Abi Waqash, Ibnu Mas'ud, Umar bin Abdul Aziz, Qasim, Urwah keluarga Abu bakar dan keluarga Ali. ${ }^{11}$

Dari Nafi' dari Abdullah bin Umar ra, bahwa ia pernah mengabarkan kepada Nafi' ra pernah mempekerjakan penduduk Khaibar dengan syarat bagi dua hasil kurmanya atau tanaman lainnya. ${ }^{12}$ Imam Bukhari menulis, Qais bin Muslim meriwayatkan dari Abu Ja'far, ia berkata:

"Seluruh Ahli Bait yang hijrah ke Madinah adalah petani dengan cara bagi hasil sepertiga dan seperempat. Di antaranya lagi yang telah melaksanakan muzara'ah adalah Ali, Sa'ad bin Malik, Abdullah bin Mas'ud, Umar bin Abdul Aziz, al-Qasim, Urwah, Keluarga Abu Bakar, Keluarga Umar, Keluarga Ali dan Ibnu Sirin."

Ulama yang menetapkan dan membolehkan hukum mukhabarah dan muzara'ah dilandaskan pada sebuah hadis yang diriwayatkan oleh Bukhari dan Muslim dari Abu Abbas ra. Yang Artinya:

“Berkata Rafi' bin Khadij: “Diantara Anshar yang paling banyak mempunyai tanah adalah kami, maka kami persewakan, sebagian tanah untuk kami dan sebagian tanah untuk mereka yang mengerjakannya, kadang sebagian tanah itu berhasil baik dan yang lain tidak berhasil, maka oleh karenanya Raulullah SAW. Melarang paroan dengan cara demikian". (H.R. Bukhari)

Artinya: Dari Ibnu Umar: "Sesungguhna Nabi SAW. Telah memberikan kebun kepada penduduk khaibar agar

\footnotetext{
${ }^{11}$ Syafi'i Antonio, Muhammad, Bank Syari'ahdariteorikePraktik, GemaInsani, Jakarta, 2009

12 Muttafaqun 'alaih: Fathul Bari VI: 13 No: 2329, Muslim XCIII: 1186 No: 1551, 'Aunul Ma’Bud IX: 272 No: 3391, Ibnu Majah II: 824 No: 2467, Tirmidzi II: 421 No: 1401.
} 
dipelihara oleh mereka dengan perjanjian mereka akan diberi sebagian dari penghasilan, baik dari buah-buahan maupun dari hasil pertahun (palawija)" (H.R Muslim)

Berdasarkan dalil di atas, ulama membolehkan muzara'ah, namun ada beberapa yang mengharamkannya di antaranya mazhab Syafi'i. Menurut Al-Syafi'iyah, hukum melakukan muzara'ah adalah haram didasarkan pada hadis diriwayatkan oleh Muslim dari Tsabit Ibn al-Dhahak yang artinya:

“Bahwa Rasulullah Saw, telah melarang bermuzara'ah dan memerintahkan sewa menyewa dan Rasulullah Saw bersabda itu tidak mengapa."

Diriwayatkan oleh Muslim dan Thawus ra. yang artinya:

"Sesungguhnya Thawus ra. Bermukhabarah, Umar ra. Berkata; dan aku berkata kepadanya; ya Abdurahman, kalau engkau tinggalkan mukhabarah ini, nanti mereka mengatakan bahwa Nabi melarangnya. Kemudian Thawus berkata; telah menceritakan kepadaku orang yang sungguh - sungguh mengetahui hal itu, yaitu Ibnu Abbas, bahwa Nabi SAW, tidak melarang mukhabarah, hanya beliau berkata bila seseorang memberi menfaat kepada saudaranya, hal itu lebih baik daripada mengambil manfaat dari saudaranya dengan yang telah dimaklumi."

Berdasarkan hadis di atas, maka dalam kitab Al-Minhaj disebutkan bahwa mukhabarah yang berarti mengerjakan tanah (menggarap ladang atau sawah) dengan mengambil sebagian dari hasilnya, sedangkan benihnya dari pekerja hukumnya tidak boleh dan tidak boleh pula bermuzara'ah yaitu mengelola tanah yang benihnya dari pengolaan tanah.

Di pendapat al-Syafi'iyyah yang lain, terdapat pandangan bahwa muzara'ah hukumnya haram, namun akad al-muzara'ah sah apabila muzara'ah mengikut kepada akad musaqah. Misalnya, apabila terjadi akad musaqah. Jika dalam pengelolaan perkebunan dengan pengairan, kemudian ada tanah kosong di antara pepohonan yang tidak mungkin tidak akan terkena pengairan dari musaqah atau tanah kosong di salah satu sudut

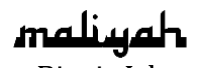


area tanah itu, maka tanah itu boleh dimanfaatkan untuk muzara'ah, artinya akad al-muzara'ah ini tidak berdiri sendiri tetapi mengikut pada akad musaqah, bila tidak demikian maka akad al-muzara'ah tidak boleh.

Ulama yang lain, seperti Nawawi, Ibnu Mundzir, dan Khatabbi membolehkan muzara'ah ataupun mukhabarah. Pendapat ini didasarkan pada hadis Ibnu Umar yang diriwayatkan oleh Imam Muslim di atas, adapun hadis yang melarang tadi maksudnya hanya apabila ditentukan penghasilan dari sebagian tanah, mesti kepunyaan salah seorang di antara mereka.

\section{Rukun Muzara'ah dan Syarat Muzara'ah}

Muzara'ah memiliki empat rukun, yaitu: Pemilik tanah, petani/penggarap, objek muzara'ah, dan Ijab dan qabul, keduanya secara lisan, bagi ulama Hanabilah, qabul tidak harus berupa lisan, namun dapat juga berupa tindakan langsung dari si penggarap. 13

Berdasarkan rukun tersebut, maka masing-masing rukun harus memenuhi syarat-syarat tertentu: Pertama, syarat-syarat yang berkaitan dengan orang yang berakad (pemilik dan petani). Pemilik lahan dan penggarap lahan disyaratkan berakal, baligh, batas-batas tanah itu jelas, tanah itu diserahkan sepenuhnya kepada petani untuk digarap, apabila pada waktu akad disyaratkan bahwa pemilik tanah ikut serta menggarap, maka akad muzara'ah ini dianggap tidak sah.

Berkaitan dengan orang murtad, jumhur ulama sepakat bahwa akad muzara'ah ini boleh dilakukan antara Muslim dan non Muslim termasuk di dalamnya orang murtad, namun sebagian ulama Hanafiyah melarang penggarap atau pemilik

${ }^{13}$ Ibid., 278.

\section{maliyath}

15i Jurnal Hukum Bisnis Islam 
dari orang murtad karena tindakan orang murtad dianggap mauquf, tidak punya efek hukum hingga ia masuk Islam. ${ }^{14}$

Kedua, berkaitan dengan objek muzara'ah, yang harus diperhatikan adalah benih, tanah dan hasil panen. Benih yang ditanam disyaratkan benih tersebut harus jelas, apa yang akan ditanam disesuaikan dengan kebiasaan tanah itu. Sedangkan syarat yang menyangkut tanah pertanian adalah menyesuaikan adat di kalangan petani, tanah itu boleh digarap dan menghasilkan, jika tidak potensial untuk ditanami karena tandus dan kering, maka muzara'ah dianggap tidak sah.

Syarat-syarat yang berkaitan dengan hasil panen adalah pembagian hasil panen bagi masing-masing pihak harus jelas, hasil itu benar-benar milik bersama orang yang berakad, tanpa ada unsur dari luar, dan pembagian hasil panen itu ditentukan pada awal akad untuk menghindari perselisihan nantinya. ${ }^{15}$

Jangka waktu pada muzara'ah juga harus ditentukan dengan jelas, karena muzara'ah mengandung unsur ijarah (sewa menyewa) dengan imbalan sebagian hasil panen. Untuk penentuan jangka waktu ini biasanya disesuaikan dengan adat dan kebiasaan setempat. Obyek akad (mahallul 'aqdi), disyaratkan juga harus jelas, baik berupa pemanfaatan jasa penggarap di mana benih berasal dari penggarap atau pemanfaatan tanah dimana benih berasal dari pemilik tanah.

Menurut Abu Yusuf dan Muhammad al Hasan, terdapat empat bentuk muzara'ah ditinjau dari sudut sah tidaknya akad muzaraa'ah, yaitu: Pertama, apabila tanah dan bibit dari pemilik tanah, sedangkan kerja dan alat dari petani, sehingga yang menjadi objek adalah jasa petani, maka akad muzara'ah dianggap sah. Kedua, apabila pemilik tanah hanya menyediakan tanah, sedangkan petani menyediakan bibit, alat dan kerja,

${ }^{14}$ Wahbah Al-Zuhaily, Al-Fiqh Al-Islamy Wa Adillatuh, Juz V(Beirut: Dar alFikr, 1998), 616.

${ }^{15}$ Haroen, Fiqh Muamalah, 279. 
sehingga yang menjadi obyek muzara'ah adalah manfaat tanah, maka akad muzara'ah dianggap sah. Ketiga, apabila tanah, alat dan bibit dari pemilik tanah dan kerja dari petani, sehingga yang menjadi obyek muzara'ah adalah jasa petani, maka akad muzara'ah juga sah. Keempat, apabila tanah dan alat disediakan oleh pemilik tanah dan bibit serta kerja dari petani, maka akad ini tidak sah.

Dalam muzara'ah tidak boleh mensyaratkan sebidang tanah tertentu, ini untuk si pemilik tanah dan sebidang tanah lainnya untuk sang petani, sebagaimana sang pemilik tanah tidak boleh mengatakan "Bagianku sekian wasaq."

Pada masa Rasulullah, terdapat suatu bentuk muzara'ah yang sudah biasa berlaku di masa itu, tetapi beliau melarangnya karena terdapat unsur-unsur penipuan dan kesamaran yang berakibat kepada pertikaian datau sengketa, dan bertentangan dengan jiwa keadilan yang sangat dijunjung tinggi oleh Islam. Ketika itu banyak para sahabat yang memberikan persyaratan kepada orang yang mengerjakan tanahnya dengan menentukan tanah dan sewanya dari hasil tanah baik berupa takaran ataupun timbangan, sedang sisa daripada hasil itu untuk yang mengerjakannya atau masih dibagi dua lagi, misalnya.

Keadilan menurut Rasulullah SAW adalah kedua belah pihak bersekutu dalam hasil tanah itu sedikit ataupun banyak. Tidak adil jika hanya satu pihak yang mendapat keuntungan, misal hanya di satu pihak mendapat bagian tertentu yang lain tidak karena tanahnya tidak menghasilkan lebih dari yang ditentukan itu. Dalam keadaan demikian maka pemilik tanah berarti akan mengambil semua hasil sedang di lain pihak menderita kerugian besar.

Untuk menghindari pertikaian dan ketidakadilan, maka seharusnya masing-masing pihak mengambil bagiannya itu dari hasil tanah dengan suatu perbandingan yang disepakati bersama. Jika hasilnya itu banyak maka kedua belah pihak akan 
ikut merasakannya dan jika hasilnya sedikit keduanya akan mendapat sedikit pula. Jika sama sekali tidak menghasilkan apa-apa maka kedua-duanya akan menderita kerugian. Cara yang demikian ini lebih menenangkan jiwa bagi kedua belah pihak.

Tujuan dari ajaran hukum Islam adalah untuk mewujudkan keadilan secara merata serta menjauhkan semua hal yang menyebabkan pertentangan dan perkelahian di kalangan masyarakat Islam. Berkaitan dengan muzara'ah, masing-masing dari pemilik tanah dan penyewa harus memiliki sikap toleransi (tasamuh) yang tinggi. Misalnya si pemilik tanah jangan minta terlalu tinggi dari hasil tanahnya itu, begitu juga sebaliknya si penyewa jangan merugikan pihak pemilik tanah.

Cara lain yaitu dengan menyewakan tanahnya tersebut dengan uang. Misalnya si pemilik tanah menyerahkan tanahnya itu kepada orang yang sanggup mengurusnya dengan penyewaan berupa uang dengan jumlah tertentu. Cara ini oleh kebanyakan ahli fiqih yang masyhur dibolehkannya, tetapi sementara ada yang melarangnya dengan dalil hadis sahih yang menerangkan bahwa Nabi Muhammad SAW melarang menyewakan tanah dengan penyewaan atau bagian tertentu. ${ }^{16}$

\section{Asas Kemaslahatan dalam Penerapan Akad Muzara'ah pada Bank Syariah}

Kamus Besar Bahasa Indonesia mendefinisikan maslahah dengan "Sesuatu yang mendatangkan kebaikan (kemaslahatan), faidah atau guna". Kemaslahatan adalah kegunaan, kebaikan, manfaat, dan kepentingan. Kata maslahah menunjuk pada arti manfaat hendak diwujudkan, guna meraih kebajikan atau suatu hal yang lebih baik dalam kehidupan umat manusia. Setiap hal yang mengandung manfaat adalah maslahah, baik dalam upaya mewujudkannya melalui usaha

${ }^{16}$ Akafa, "Pengertian Muzara’ah."

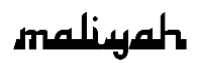

Jurnal Hukum Bisnis Islam

Volume 8, Nomor 2, Desember 2018 p-ISSN: 2088-4869/ e-ISSN: 2597-4351 
meraihnya (jalb al-mashalih) atau menghindarkan hal yang menyebabkan kerusakan (dar' al-mafasid).$^{17}$

Akan tetapi maslahah terkadang diartikan sebagai kebaikan yang terjadi atau yang digunakan untuk keperluan pribadi. Menurut al-Syathibi, bahwa tidak semua maslahah dapat dijadikan penetapan hukum. Maslahah yang dapat dijadikan pijakan adalah kemaslahatan yang telah ditetapkan syari' atau sejalan dengan tujuan-tujuannya; bukan kemaslahatan yang nyata-nyata berlawanan dengan kehendak syar'i. ${ }^{18}$ Dimaksudkan kehendak syar'i adalah hal-hal yang sesuai dengan ajaran agama Islam yang telah ditetapkan pada al-Qur'an dan hadis.

Dalam kontek ekonomi, Islam telah memberikan jalan keluar bagi manusia agar tetap pada jalur-jalur yang benar demi kemaslahatan dan kemajuan manusia. Islam sebagai sebuah ajaran telah memberikan rambu-rambu normative sebagai arahan praktik bagi manusia di lapangan. Salah satu ajaran normative dalam Islam adalah dibahas tentang muzara'ah dan mukhabarah atau terkenal dengan istilah pertanian. ${ }^{19}$

Berkaitan dengan optimalisasi akad muzara'ah pada bank syariah, ada beberapa hal yang perlu diperhatikan, di antaranya:

1. Memperbaiki sistem bank sesuai visi bank syariah yang sesungguhnya.

Memberikan kemaslahatan merupakan tujuan utama dari pengembangan perbankan syariah. Perbankan syariah

\footnotetext{
17 Tim Penyusun Kamus Pusat Penelitian dan Pengembangan Bahasa, Kamus Besar Bahasa Indonesia (Jakarta: Balai Pustaka, 1989).

18 "Http://Id.Shvoong.Com/Humanities/Religion-Studies/2114748-PengertianMaslahah/ixzz1 uEyFOeCJ.," 2012.

19 Rasiam, "Relasi Sosio-Ekonomi Petani Dengan Pemilik Lahan Melalui Konsep Mukhābarah Dan Muzāra'ah Di Desa Arang Limbung Kecamatan Sungai Raya Kabupaten Kubu Raya,” Al-Maslahah 12, no. 2 (2016), 426.
} 
diharapkan dapat bermanfaat bagi masyarakat dan berkontribusi secara optimal bagi perekonomian nasional. Sistem perbankan syariah yang ingin diwujudkan oleh Bank Indonesia adalah perbankan syariah yang modern, yang bersifat universal, terbuka bagi seluruh masyarakat Indonesia tanpa terkecuali. ${ }^{20}$ Dengan cara demikian, maka upaya pengembangan sistem perbankan syariah akan senantiasa dilihat dan diterima oleh segenap masyarakat Indonesia sebagai bagian dari solusi atas berbagai permasalahan negeri.

Cara tersebut seharusnya bisa dirasakan oleh masyarakat apabila perbankan syariah benar-benar menjalankan dengan benar visinya yang diwujudkan dengan pelaksanaan misinya, yakni pemerataan kontribusi berupa pembiayaan yang berbentuk berbagai macam akad salah satunya muzara'ah. Dengan didukungnya sumber daya alam di Indonesia yang bertepatan dengan visi bank syariah yang diutarakan oleh bank Indonesia.

2. Memperbaiki sistem pertanian

Sektor pertanian merupakan sektor yang mempunyai peranan penting dalam suatu negara, namun perhatian pemerintah terhadap sektor pertanian terbilang masih kurang yang akibatnya sektor pertanian di Indonesia mengalami perkembangan yang cukup lambat. Hambatan para petani dalam mengembangkan atau memperluas lahannya pada umumnya yaitu modal. Masalah permodalan ini disebabkan akses pembiayaan yang tidak dimiliki oleh petani. Masalah permodalan pembiayaan pertanian sektor kecil pada lembaga keuangan formal menjadi kompleks

\footnotetext{
20

"Perbankan

Syariah," 2012 , http://www.bi.go.id/web/id/Perbankan/Perbankan+Syariah/ . Tanggal akses 04/06/2012.
} 
disebabkan petani tidak mampu memenuhi persyaratan administrasi sehingga dinyatakan tidak bankable. ${ }^{21}$

Terdapat beberapa faktor yang menyebabkan petani mengalami kesulitan untuk memperoleh akses pembiayaan. Faktor tersebut adalah: Pertama, disebabkan ketidakmampuan petani dalam menyediakan agunan, terbatasnya jumlah dan jangkauan operasi bank sementara para petani rata-rata hidup di pedesaan, kondisi pertanian yang besifat long-term berhadapan dengan kebutuhan perbankan yang short term untuk memenuhi kebutuhan likuiditas.

Kedua, faktor lain yang turut mempengaruhi adalah Sumber Daya Manusianya yang rendah. Rata-rata para petani mengenyam pendidikan hanya sampai pada level yang sangat rendah. Dampaknya, pengelolaan pertanian berjalan tidak optimal, sulit mendapat akses pembiayaan karena terbatasnya pengetahuan untuk membuat proposal/cash flow usaha, rendahnya daya saing hasil pertanian karena terbatasnya sarana dan peran tekhnologi yang digunakan.

Ketiga, adanya stigma negatif dan persepsi bahwa sektor pertanian berisiko tinggi, bergantung pada musim, ketersediaan air, jaminan harga yang fluktuatif, dan sebagainya. $^{22}$ Dari sinilah, peran perbankan syariah sangat diharapkan dalam menggerakkan sektor pertanian di Indonesia.

Bank syariah lebih cocok berperan terhadap pertanian daripada bank konvensional. Karena didasari oleh beberapa hal, yakni:

${ }^{21}$ Ahmad Ajib Ridlwan, "Implementation Akad Muzara'ah in Islamic Bank: Alternative to Access Capital Agricultural Sector," Iqtishoduna 7, no. 1 (2016), 36.

22 Mujadid, "Bank Syariah Pro Pertanian," 2012, http://mujadid83.wordpress.com/2008/02/27/bank-syariah-pro-pertanian/. Tanggal akses 04/06/2012. 
1. Secara filosofis, perbankan syariah memiliki ikatan yang kuat dengan sektor pertanian. Masyarakat petani yang selama ini sudah terbiasa dengan sistem bagi hasil, seperti mudharabah, musyarakah dan muzara'ah memudahkan bank syariah untuk masuk ke jantung sektor pertanian.

2. Kedua, melihat antara sistem syariah dengan sistem bunga (konvensional) yang lebih cocok dalam pedesaan adalah sistem syariah, sistem syariah lebih sesuai dengan karakter petani dan pertanian di Indonesia dibandingkan dengan sistem bunga karena dianggap menguntungkan bagi petani.

Muzara'ah yaitu kerja sama pengolahan pertanian antara pemilik lahan dengan penggarap, dimana pemilik lahan memberikan lahan pertanian kepada si penggarap untuk ditanami dan dipelihara dengan imbalan bagian tertentu (persentase) dari hasil panen. ${ }^{23}$ Indonesia adalah negara kepulauan terbesar di dunia yaitu terdiri dari 17.508 pulau Dengan populasi sebesar 222 juta jiwa pada tahun 2006, Indonesia adalah negara berpenduduk terbesar keempat di dunia. $^{24}$

Kebanyakan orang-orang Indonesia juga memanfaatkan daratan Indonesia untuk bercocok tanam atau bertani. dari sektor pertanian inilah Indonesia menjadi penyuplai berbagai hasil bumi ke beberapa negara lain. lain:

Hal-hal yang mendukung muzara'ah di Indonesia antara

1. Tanah

Tidak bisa dipungkiri lagi bahwa tanah di Indonesia adalah tanah yang subur, kebanyakan jenis tanaman bisa untuk ditanam di Indonesia. bandingkan dengan di Jepang maupun

${ }^{23}$ Muhammad Syafii Antonio, Bank Syariah: Dari Teori Ke Praktik (Jakarta: Gemma Insani, 2001), 99.

24 "Definisi Tentang Negara Kesatuan Republik Indonesia," 2012, http://www.g-excess.com/444/definisi-tentang-negara-kesatuan-republikindonesia/. Tanggal akses 04/06/2012. 
di Arab Saudi. Sejak Jepang di bom oleh tentara sekutu pada tahun 1942, tanah di Jepang jadi gersang dan tidak bisa ditumbuhi apapun, begitu pula di Arab Saudi yang tanah di sana bisa dikatakan buruk karena asupan airnya dan terlalu banyak terkena terik panas matahari akibatnya tumbuhan yang tumbuh di Arab Saudi hanyalah tumbuhan yang tidak butuh air dalam perkembangannya seperti kurma dan kaktus.

2. Iklim

Iklim di Indonesia adalah tropis. iklim di Indonesia juga sangat membantu dalam hal pertanian. Sebagaimana diketahui bahwa tumbuhan-tumbuhan itu harus memperoleh terik matahari yang cukup dan kandungan air yang cukup pula. Di Jawa Timur juga banyak sekali tanah atau lahan yang kurang dirawat oleh pemiliknya, terutama di wilayah-wilayah pedesaan yang memang daerahnya banyak terdiri dari lahan-lahan kosong, hal ini dikarenakan pemilik lahan tidak memiliki waktu untuk merawat lahan dan mereka malas karena harus berpanas-panasan untuk merawat lahan yang dimilikinya.

Di sisi lain banyak juga orang yang tidak mempunyai lahan tapi mereka mempunyai banyak waktu untuk berkerja. Diantara mereka banyak yang hidup dalam kemiskinan karena tidak mempunyai pekerjaan. Maka dari itu, usaha yang dilakukan para pemilik lahan adalah kerjasama dengan penggarap lahan. Dengan begitu para pemilik lahan dan orang yang tidak memiliki lahan bisa saling memanfaatkan sesuatu hal yang dianggap mubadzir jika dilewatkan.

Sistem muzara'ah sangat membantu para pemilik lahan yang tidak mempunyai waktu untuk menggarap dan merawatnya. Muzara'ahi juga membantu orang-orag yang tidak memiliki lahan tapi memiliki keahlian dalam bertani. Sistem muzara'ah sebenarnya sudah dikenal dan dipraktekkan di kalangan masyarakat khususnya di Indonesia, yang mungkin dengan berbagai macam istilah dan penamaan. Penerapan sistem ini pada umumnya dapat dilihat pada masyarakat 
pedesaan yang hidupnya mengandalkan pertanian. Sistem ini akan membentuk kerjasama antara pemilik lahan dan petani penggarap yang didasari rasa persaudaraan antara kedua belah pihak.

Dalam hal ini aplikasi muzara'ah sangat cocok dengan keadaan yang ada di pedesaan. Alasan muzara'ah cocok untuk diterapkan di pedesaan adalah disebabkan beberapa faktor, diantaranya:

1. Para pemilik lahan tidak punya waktu.

Para pemilik lahan biasanya adalah orang yang kaya yang sudah mempunyai bisnis lain selain mengurus lahan, maka dari itu orang dalam kategori ini lebih memilih mengurusi bisnis tersebut dan mengabaikan lahan-lahan yang dimilikinya. Alasan lain yang membuat orang di kategori ini malas mengurus lahannya adalah karena mereka malas berpanas-panasan, karena sudah ada bisnis yang lebih nyaman dengan orang tersebut.

2. Banyaknya orang-orang yang tidak punya lahan.

Orang-orang yang tidak memiliki lahan biasanya mereka hidupnya dalam kemiskinan karena tidak mempunyai perkerjaan. Faktor utama mereka yang tidak mempunyai lahan menjadi alasan yang tidak bisa terbantahkan karena rata-rata penduduk pedesaan banyak yang menggantungkan hidupnya dengan hal yang menyangkut masalah pertanian. Biasanya orang-orang seperti ini sulit dalam ekonomi yang mengakibatkan mereka tidak bisa memiliki lahan dan mungkin mereka membutuhkan perhatian dari pemerintah yang berupa materi yang bertujuan untuk sedikit membantu mereka.

3. Rendahnya pendidikan.

Kebanyakan orang-orang pedesaan banyak yang pendidikannya masih kurang, mereka kebanyakan hanya lulusan SD, SMP dan SMA. banyak kalangan yang menganggap pendidikan itu tidak penting karena bagi mereka mungkin sekolah hanya menghambur-hamburkan uang untuk biaya sekolah itu, maka dari itu mereka memutuskan tidak melanjutkan pendidikannya. Tetapi pada 
kenyataannya mereka tidak bisa berkerja dengan mengandalkan ijasah SMA karena orang-orang yang membuka lapangan pekerjaan pasti memilih orang yang berpendidikan minimal SMA untuk diperkerjakan. Dengan begitu orang-orang yang tidak mempunyai perkerjaan tersebut hanya bisa mengandalkan pendapatan dari pertanian untuk menyambung hidupnya dan itupun mereka harus mencari lahan yang sekiranya tidak begitu dirawat oleh pemiliknya.

4. Tradisi

Tradisi orang-orang pedesaan memang banyak yang mengandalkan hasil dari pertanian. dengan menekuni bidang pertanian warga pedesaan tersebut menggantungkan nasibnya. Karena biasanya di daerah daerah tertentu itu ada yang menganggap bahwa bercocok tanam adalah sebuah tradisi yang harus dijalankan dari masing-masing rumah tangga.

Konsep muzara'ah adalah kerja sama dengan bagi hasil dalam pengelolaan pertanian antara petani pemilik lahan dengan petani penggarap. Konsep kerja sama bagi hasil dalam pertanian juga ada pada mukhabarah. Perbedaan antara muzara'ah dan mukhabarah adalah terletak pada asal benih yang ditanam. Jika benihnya berasal dari petani pemilik lahan biasa disebut dengan mukhabarah, sebaliknya jika benihnya berasal dari petani penggarap biasa disebut dengan muzara'ah.

Praktek muzara'ah mengacu pada prinsip Profit and Loss Sharing System. Hasil akhir menjadi patokan dalam praktek muzara'ah. Jika, hasil pertaniannya mengalami keuntungan, maka keuntunganya dibagi antara kedua belah pihak, yaitu petani pemilik sawah dan petani penggarap. Begitu pula sebaliknya, jika hasil pertaniannya mengalami kerugian, maka kerugiannya ditanggung bersama.

Dasar yang menjadi acuan praktek muzara'ah adalah hadis Nabi SAW. Diantaranya, Hadits Riwayat Imam Bukhari dari Jabir yang menyatakan bahwa kaum Arab senantiasa 
mengolah tanahnya secara muzara'ah dengan rasio bagi hasil 1/3:2/3, 1/4:3/4, 1/2:1/2:

Rasulullah SAW pun bersabda: "Hendaklah menanami atau menyerahkannya untuk digarap, barangsiapa tidak melakukan salah satu dari keduanya, tahanlah tanahnya."

Dalam kehidupan masyarakat di bidang pertanian, pembagian hasil paroan sifatnya adalah bervariasi, ada yang mendapat setengah, sepertiga, ataupun lebih rendah dari itu. Bahkan terkadang cenderung merugikan pihak penggarap atau petani. Bagi umat Islam di Indonesia sudah ada ketentuan khusus mengenai pembagian hasil paroan bidang pertanian ini, yaitu Surat Keputusan Bersama Menteri Dalam Negeri dan Menteri Pertanian Nomor 211/1980 dan Nomor 714/Ppts/Um/9/1980, yang menjelaskan tentang perimbangan hak antara pemilik tanah dan penggarap, yakni masing-masing seperdua bagian atau seimbang.

Di sisi lain, tidak boleh dijanjikan pihak yang lain akan mengambil bagian yang lainya apabila terjadi kerusakan. Misalnya pemilik lahan boleh mengambil bagian penggarap apabila lahan bagiannya mengalami kegagalan panen, atau tanaman di atas tanah bagianya rusak. Atau sebaliknya, tidak boleh dijanjikan penggarap mengambil bagian pemilik lahan apabila bagian penggarap gagal panen atau rusak.

\section{Peran Bank Syariah dalam Perkembangan Pertanian di Indonesia}

Kehadiran lembaga perbankan syariah sangat tepat untuk mengembangkan sektor agribisnis, baik bank umum syariah maupun Bank Perkreditan Rakyat Syariah. Hal ini dikarenakan bank syariah menggunakan skema bagi hasil (mudharabah, muzara'ah, musyarakah). Secara garis besar, aplikasi muzara'ah dalam perbankan syariah dapat digambarkan sebagai berikut: 


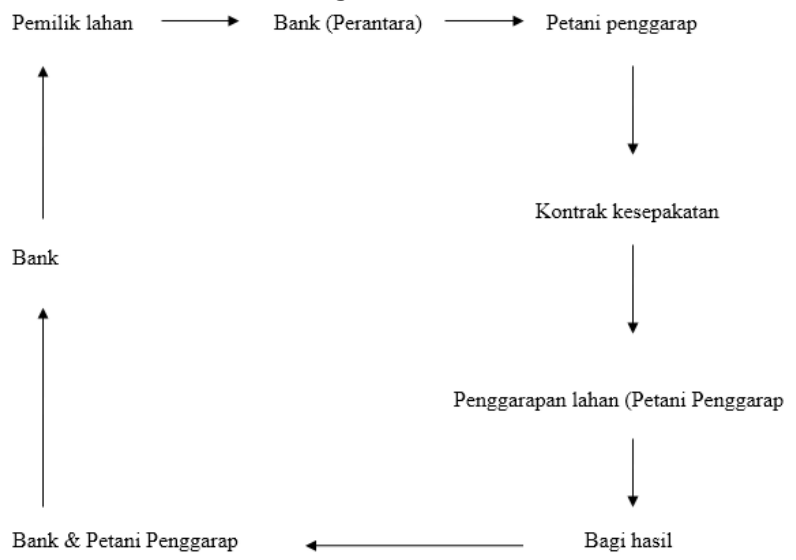

$\begin{array}{clcc}\text { Pemilik lahan menginvestasikan lahannya } & \text { map lahan, } \\ \text { kepada bank untuk dicarikan penggarap }\end{array}$ jadi peran dari bank tersebut adalah sebagai perantara antara pemilik lahan dengan penggarap lahan yang artinya bank tidak perlu membeli lahan untuk penggarap namun menggunakan investasi lahan dari pemilik lahan untuk pembiayaan akad muzara'ah kepada penggarap lahan.

Setelah disepakati, digarap dan panen maka hasil dari panen itu dibagi antara bank dengan penggarap lahan sesuai kesepakatan awal dan pihak bank juga memberi bagian kepada investor lahan. Jadi pada intinya bank tidak akan rugi seandainya penggarap lahan gagal memanfaatkan lahan tersebut.

Maka dari itu peranan Bank Syariah di Indonesia sangatlah dibutuhkan bagi sektor pertanian khususnya dalam pembiayaan akad muzara'ah, pembiayaan muzara'ah sangatlah penting bagi petani-petani yang ingin mengembangkan lahan pertaniannya agar dapat terwujudnya kemaslahatan bersama yang artinya bagus dalam kualitas dan pendapatannya dari individu maupun sosial. 
Keuntungan bagi pemerintah ketika munculnya produk muzara'ah di perbankan syariah sebagai berikut:

1. Pendapatan dalam segi PDB akan semakin meningkat karena ada penambahan pendapatan dari sektor pertanian yang saat ini semakin terpuruk

2. Tingkat pengangguran akan semakin berkurang karena adanya lahan kerja baru

3. Tingkat kemiskinan akan semakin berkurang karena sebagian besar masyarakat indonesia yang bekerja menjadi buruh tani/petani telah mendapatkan sumber dana yang konkrit untuk mengembangkan usahanya.

4. Tingkat aktivitas pengimporan beras dari negara lain akan semakin berkurang karena petani beras dalam negeri mampu memnuhi kebutuhan dalam negeri.

5. Jika kebutuhan dalam negeri terpenuhi maka kelebihan produksi dapat diekspor ke luar negeri. Sehingga membuka perekonomian 4 sektor bagi Indonesia.

6. Jika ekspor beras meningkat maka perolehan mata uang asing akan meningkat pula.

7. Dapat mengimbangi pertumbuhan penduduk indonesia yang saat ini semakin meledak. Karena hasil pertanian dibutuhkan oleh populasi di daerah terlebih lagikota yang semakin meningkat.

8. Meningkatkan kebutuhan akan barang-barang pabrikan yang mendukung kemajuan pertanian.

9. Pembentukan modal yang akan menambah sirkulasi perputaran uang (moneter) di indonesia.

10. Peningkatan mata uang asing dari hasil subtitusi impor produk pertanian.

11. Integrasi antara sektor pertanian dengan ekonomi nasional melalui infrastruktur dan pasar.

12. Dengan terbangunnya integrasi kedua sektor diatas maka perekonomian akan meningkat.

13. Perekonomian meningkat juga akan mempengaruhi penurunan tingkat kemiskinan. 
Dibutuhkan regulasi dari pemerintah sebagai upaya medukung berjalannya produk baru perbankan syariah yakni akad muzara'ah, diantaranya:

1. Pengendalian permintaan dan penawaran

Dikarenakan elastisitas untuk produk pangan ada inelastis sehingga sangat peka terhadap perubahan harga. Maka pemerintah hendaknya menyeimbangkan antara permintaan dan penawarannya, sehingga tidak terjadi kekurangan penawaran yang dapat mengakibatkan berhentinya pemasokan hasil pertanian ke pasar, yang membuat petani merugi.

2. Penetapan harga

Kesalahan dalam penetapan harga menyebabkan banyak masalah. Misalnya dalam menetapkan harga eceran yang telalu rendah dapat mengakibatkan subsidi pemerintah yang terlalu besar. Pemberian subsidi yang tidak diperhitungkan dengan matang juga akan menimbulkan kekacauan dalam sektor-sektor yang terkait.

3. Memacu timbulnya iklim investasi

Dikatakan investasi sangatlah penting karena menyangkut pertumbuhan negara. Karena disinilah petani dapat mengembangkan lahan atau usahanya dikarenakan adanya tambahan modal. Baik modal materi ataupun non materi.

4. Tidak berhenti meningkatkan mutu SDM

Tidak ada gunanya pula investasi dan regulasi pemerintah yang sangat baik. Apabila sumber daya manusia yang diberi tanggung jawab untuk mengolah tidak dapat mengemban amanah. Maka dari itu pemerintah dianjurkan bagi pemerintah untuk memberikan pelatihan bagi petani-petani tersebut. Meski petani tersebut dalam naungan sebuah bank, pemerintah tetap bisa mengupayakan partisipasi dalam meningkatkan SDM dengan memberikan insentif pada bank tersebut. Apabila pemerintah ingin terjun langsung, maka pemerintah dapat mengutus menteri dalam bidang ketenaga kerjaan untuk melakukan kegiatan apapun yang dapat meningkatkan mutu SDM.

5. Memaksimalkan teknologi 
Negara ini tidak hanya ingin disebut sebagai negara berkembang melainkan negara yang maju tentunya. Maka dari itu dengan mengikuti perkembangan teknologi saat ini khususnya dalam bidang pertanian. Penggunaan teknologi yang modern pun tidak harus membeli dari negara tetangga. Pemerintah dapat memaksimalkan anak negeri yang tidak kalah berbakatnya dalam menciptakan teknologi yang mutakhir. Sehingga dalam upaya pemerintah mendukung akan muzara'ah ini, dalam sektor pendidikan dan pengembangan anak bangsa juga dapat teroptimalisasikan.

\section{Penutup}

Berdasarkan pembahasan di atas maka dapat disimpulkan bahwa muzara'ah adalah menggarap tanah orang lain seperti sawah atau ladang dengan imbalan sebagian hasilnya (seperdua, sepertiga atau seperempat), sedangkan biaya pengerjaan dan benihnya ditanggung pemilik tanah.

Dalam kajian hukum Islam, ulama berbeda pendapat tentang hukum muzara'ah, ada yang membolehkan dan ada yang mengharamkan. Dasar yang menjadi acuan diperbolehkannya praktek muzara'ah adalah hadis Nabi SAW. yang bersabda: "Hendaklah menanami atau menyerahkannya untuk digarap, barangsiapa tidak melakukan salah satu dari keduanya, tahanlah tanahnya."

Praktek muzara'ah harus memenuhi rukun dan syarat yang telah ditentukan. Rukun muzara'ah adalah pemilik tanah, petani/penggarap, objek muzara'ah, dan Ijab dan qabul.

Praktek muzara'ah mengacu pada prinsip Profit and Loss Sharing System. Hasil akhir menjadi patokan dalam praktek muzara'ah. Jika, hasil pertaniannya mengalami keuntungan, maka keuntunganya dibagi antara kedua belah pihak, yaitu petani pemilik sawah dan petani penggarap. Begitu pula sebaliknya, jika hasil pertaniannya mengalami kerugian, maka kerugiannya ditanggung bersama. 
Berkaitan dengan optimalisasi akad muzara'ah pada bank syariah, ada beberapa hal yang perlu diperhatikan, di antaranya dengan memperbaiki sistem bank sesuai visi bank syariah yang sesungguhnya dan memperbaiki sistem pertanian. Pembiayaan muzara'ah sangat penting bagi petani yang ingin mengembangkan lahan pertaniannya agar dapat terwujudnya kemaslahatan bersama yang artinya bagus dalam kualitas dan pendapatannya dari individu maupun sosial.

Untuk mendukung optimalnya akad ini, maka dibutuhkan dukungan dari pemerintah diantaranya melalui pengendalian permintaan dan penawaran, penetapan harga, memacu timbulnya iklim investasi, tidak berhenti meningkatkan mutu SDM, dan memaksimalkan teknologi.

\section{Daftar Pustaka}

Akafa. "Pengertian Muzara'ah," 2012. http://akafapendidikan.blogspot.com/2012/01/pengertianmuzaraah.html?zx=a9a2170cc9273cfb.

Al-Khalafi, Abdul Azhim bin Badawai. Al-Wajiz Fi Fiqh as Sunnah Wa Al Kitab Al Aziz, Edisi Indonesia Panduan Fiqih Lengkap, Ter. Team Tashfiyah LIPIA. Jakarta: Pustaka Ibnu Kasir, 2007.

Al-Zuhaily, Wahbah. Al-Fiqh Al-Islamy Wa Adillatuh. Beirut: Dar al-Fikr, 1998.

Antonio, Muhammad Syafii. Bank Syariah: Dari Teori Ke Praktik. Jakarta: Gemma Insani, 2001.

“Definisi Tentang Negara Kesatuan Republik Indonesia," 2012. http://www.g-excess.com/444/definisi-tentang-negarakesatuan-republik-indonesia/. Tanggal akses 04/06/2012. Haroen, Nasroen. Fiqh Muamalah. Jakarta: Gaya Media Pratama, 2000.

"Http://Id.Shvoong.Com/Humanities/Religion-

Studies/2114748-Pengertian-

Maslahah/\#ixzz1uEyFOeCJ.," 2012.

Mujadid. "Bank Syariah Pro Pertanian," 2012. http://mujadid83.wordpress.com/2008/02/27/banksyariah-pro-pertanian/. Tanggal akses 04/06/2012. 
"Muttafaqun 'alaih: Fathul Bari VI: 13 No: 2329, Muslim XCIII: 1186 No: 1551, 'Aunul Ma'Bud IX: 272 No: 3391, Ibnu Majah II: 824 No: 2467, Tirmidzi II: 421 No: 1401," n.d.

Ngasifudin, Muhammad. "Aplikasi Muzara'ah Dalam Perbankan Syariah.” Jurnal Ekonomi Syariah Indonesia 6, no. 1 (2016). "Perbankan Syariah," 2012. http://www.bi.go.id/web/id/Perbankan/Perbankan+Syar iah/ . Tanggal akses 04/06/2012.

Rasiam. "Relasi Sosio-Ekonomi Petani Dengan Pemilik Lahan Melalui Konsep Mukhābarah Dan Muzāra'ah Di Desa Arang Limbung Kecamatan Sungai Raya Kabupaten Kubu Raya." Al-Maslahah 12, no. 2 (2016).

Rasjid, Sulaiman. Fiqih Islam. Bandung: Sinar Baru Algensindo, 2004.

Ridlwan, Ahmad Ajib. "Implementation Akad Muzara'ah in Islamic Bank: Alternative to Access Capital Agricultural Sector." Iqtishoduna 7, no. 1 (2016).

S, Zainuddin, and Eno Suhandani. "Muzara'ah Dan Kesejahteraan Masyarakat Luwu Timur." Jurnal Muamalah 6, no. 1 (2016).

Sihaloho, Martua, Heru Purwandari, and Dyah Ita Mardiyaningsih. "Reforma Agraria Dan Revitalisasi Pertanian Di Indonesia:Studi Kasus Pertanian Tanaman Pangan Dan Hortikultura Di Jawa Barat." Sodality: Jurnal Transdisiplin Sosiologi, Komunikasi, Dan Ekologi Manusia 4, no. 1 (2010).

Suherman. "Penterapan Prinsip Bagi Hasil Pada Perbankan Syariah Sebuah Pendekatan Al-Maqasidu Al-Syariah." Al Mashlahah Jurnal Hukum Dan Pranata Sosial Islam 2, no. 3 (2014).

Tim Penyusun Kamus Pusat Penelitian dan Pengembangan Bahasa. Kamus Besar Bahasa Indonesia. Jakarta: Balai Pustaka, 1989.

Ulfa, Radian. “Analisis Pengaruh Muzara'ah Terhadap Tingkat Kesejahteraan Petani (Studi Kasus Di Desa Simpang Agung Kabupaten Lampung Tengah)." IAIN Metro, 2017.

Yunari, Afrik. "Muzara'ah Dan Aplikasinya Pada Perbankan 
Irwan Rahmatullah Putra, M. Syahrul Hajj, Ikayanti

Syari'ah." Inovatif 2, no. 2 (2016). 